\title{
The impact of diurnal fasting during Ramadan on the lipid profile, hs-CRP, and serum leptin in stable cardiac patients
}

This article was published in the following Dove Press journal:

Vascular Health and Risk Management

29 December 2011

Number of times this article has been viewed

\author{
Hadi Abdul Ridha Hadi \\ Khafaji' \\ Abdulbari Bener ${ }^{2}$ \\ Mohammed Osman ${ }^{3}$ \\ Ajayeb Al Merri ${ }^{4}$ \\ Jassim Al Suwaidi' \\ 'Department of Cardiology \\ and Cardiovascular Surgery, \\ ${ }^{2}$ Department of Medical Statistics \\ and Epidemiology, Hamad \\ General Hospital, Hamad Medical \\ Corporation, Doha, State of Qatar; \\ ${ }^{3}$ Department of Biochemistry, \\ ${ }^{4}$ Department of Serology, Hamad \\ Medical Corporation, Doha, \\ State of Qatar
}

Aim: To study the effect of strict prolonged fasting on lipid profile, serum leptin, and high-sensitivity C-reactive protein (hs-CRP) in patients with different stable cardiac illnesses and look for associated new cardiac events and any correlation between entire variables.

Methods: A total of 56 patients of different stable cardiac illnesses were followed in our cardiology outpatient for 3 months. Data concerning their ability to fast were collected: New York Heart Association class of congestive cardiac failure, angina class, previous myocardial infarction, previous coronary artery bypass graft, percutaneous coronary intervention, severity of valvular lesion, metallic prosthetic valve, and traditional risk factors (diabetes mellitus, insulin requirement, hypertension, hypercholesterolemia, smoking habit, and obesity). Detailed clinical examination and electrocardiography were performed in all patients in three consecutive visits before, during, and after Ramadan. Echocardiographic and angiographic findings and medication plans were collected from patient records. Lipid profile, serum leptin, and hs-CRP were assessed before, during, and after Ramadan.

Results: All patients fasted during Ramadan: $80.4 \%$ were male, $67.9 \%$ were aged $>50$ years, $71.4 \%$ had no change in their symptoms during fasting while $28.6 \%$ felt better. No patient has deteriorated. $91.1 \%$ of the patients were compliant with medicine during Ramadan, $73.2 \%$ after. $89.3 \%$ were compliant with diet during Ramadan with no significant change in body weight in the follow-up period. No cardiac or noncardiac morbidity or mortality was reported. High-density lipoprotein-cholesterol (HDL-C) decreased significantly during compared to before fasting $(P=0.012)$. Low-density lipoprotein-cholesterol (LDL-C) significantly increased during compared to before fasting $(P=0.022)$. No statistically significant changes were observed in total cholesterol (TC), triglycerides (TG), serum leptin, or hs-CRP. Significant correlation was observed between TC and hs-CRP during fasting $(P=0.036)$, but not with TG, LDL-C, or HDL-C $(P>0.05)$. Neither of these correlated with serum leptin $(P>0.05)$, but significant correlation was observed between hs-CRP and serum leptin $(P<0.05)$.

Conclusion: Ramadan fasting in stable cardiac patients has no effect on their clinical status, serum leptin, or hs-CRP, but results in decrease in HDL-C, increase in LDL-C, with significant correlation between TC and hs-CRP during Ramadan, but not with TG, LDL-C, or HDL-C, and with significant correlation between hs-CRP and serum leptin before, during, and after fasting. Keywords: serum leptin, hs-C-reactive protein, lipid profile, cardiac disease, Ramadan fasting

\section{Introduction}

Jassim Al Suwaidi Department of Cardiology and Cardiovascular Surgery, Hamad Medical Corporation, Hamad General Hospital, PO Box 3050, Doha, State of Qatar

Tel +974 4392483

Fax +974 4392454

Email jha0I@hmc.org.qa
The Islamic fast during the month of Ramadan, during which a whole month is dedicated to fasting is particular to Islam, and is strictly observed by millions of Muslims worldwide. Since more than a billion people worldwide follow Islam, it is assumed that hundreds of millions of people observe the Ramadan fast each year. ${ }^{1,2}$ 
From a physiological standpoint, Islamic fasting provides a unique fasting model. It is distinct from regular voluntary or experimental fasting by the fact that the observant of the fast does not drink during fasting which may reach more than 12 hours. Therefore, one may assume that physiological changes occurring during Islamic fasting would be different from those noted during an experimental fast. ${ }^{3,4}$ Studies on the effect of Ramadan fasting on blood lipids have produced variable results. ${ }^{5-9}$ Among patients with known stable coronary disease, a correlation between serum C-reactive protein (CRP) and acute coronary events has been demonstrated in some studies. ${ }^{10-12}$ In addition, high-sensitivity CRP (hs-CRP) has been shown in some studies to be affected by fasting, weight loss, and with postchallenge glycemia than with fasting glucose levels in nondiabetic subjects. ${ }^{13-16}$

More recently, leptin was found to have multiple roles in the cardiovascular system as a vasoactive substance, in coronary artery vasoreactivity, regulation of myocardial blood flow, ${ }^{17}$ may also have a prothrombotic effect, ${ }^{18}$ and may increase with acute myocardial infarction (AMI). ${ }^{19}$ Serum leptin was independently associated with serum CRP, suggesting that body fat may be the most significant predictor of CRP. ${ }^{20}$

The most frequently asked question by cardiac patients to their cardiologist is whether Ramadan fasting has any adverse effect on their cardiac status. The answer has not yet been clarified. We have previously reported alteration in the time of onset of cardiac events during Ramadan fasting when compared with the rest of the year, where there was a peak of cardiac events during the "breaking of fast" period. ${ }^{21}$ On the other hand, the prevalence of hospitalization for acute coronary syndrome ${ }^{22,23}$ and heart failure ${ }^{3}$ were not different from the remaining months of the year. The current study complements our previous reports in studying the impact of Ramadan fasting on serum leptin, CRP, and lipid profile among ambulatory patients with stable coronary artery disease.

Our aim was to study the effect of strict and prolonged Ramadan fasting on lipid profile, serum leptin, and hs-CRP in stable cardiac patients and check whether there were any new adverse cardiac events and whether there is any correlation between these entire variables.

\section{Subjects and methods Study design}

This prospective study was conducted at the cardiology outpatient department of Hamad General Hospital. Different classes of stable cardiac patients were followed for
3 months with three consecutive visits before, during, and after Ramadan. The study was approved by the hospital Institutional Review Board and informed consent was obtained from all patients.

Baseline clinical characteristics include age, gender, cardiovascular risk factors, and primary as well as secondary cardiovascular diagnoses were recorded. Patients with angina pectoris were subclassified according to the Canadian Cardiovascular Society classification of effort angina (I to IV). In addition, patients with congestive heart failure were subclassified according to the New York Heart Association classification (I to IV). Patients were carefully examined for the presence of clinical signs of heart failure and the findings were recorded. Their body weight and height were recorded and subsequently body mass index (BMI) was calculated. Electrocardiographic, angiographic, and echocardiographic findings were recorded as well as previous revascularization and cardiac surgical procedures. Patients subsequently were evaluated during the middle of Ramadan to see whether they were able to continue fasting or if they were hospitalized for a cardiac-related reason or developed cardiac events. ${ }^{23}$

\section{Definitions}

Congestive heart failure (CHF) was defined using the Framingham Heart Study criteria and acute coronary syndromes including AMI and unstable angina were defined according to World Health Organization guidelines as reported previously. ${ }^{3}$ The presence of diabetes mellitus and hypertension were determined by the patient's previous or current medical records of a documented diagnosis of diabetes mellitus and hypertension that had been treated with medications. The presence of hyperlipidemia was determined by the demonstration of a fasting cholesterol $>5.2 \mathrm{mmol} / \mathrm{L}$ in the patient's medical record, or any history of treatment for hyperlipidemia by patient's physician. The study was approved and sponsored by Hamad Hospital research committee.

\section{Biochemical and immunological analyses}

Fasting blood samples were collected from each patient in the middle of Ramadan between 9 am and 11 am a month before and month after at the same time as the nonfasting sample. All samples were separated and analyzed immediately with exception of serum leptin. Aliquots for serum leptin were stored at $-80^{\circ} \mathrm{C}$ until the collection was completed.

Leptin concentrations were measured with ELISA. Linco Research, Inc (St. Charles, MO) supplied the reagents. 
The measuring range was $0.5-100 \mathrm{ng} / \mathrm{mL}$. According to the manufacturer, the assay has high correlation with radioimmunoassay for human leptin $(\mathrm{r}=0967)$, its lower detection limit was $0.5 \mathrm{ng} / \mathrm{mL}$ and the variation in plasma leptin concentrations of $3.2 \mathrm{ng} / \mathrm{mL}$ and $8.18 \mathrm{ng} / \mathrm{mL}$ were $5 \%$ and $3.0 \%$, respectively. ${ }^{24}$

Total cholesterol (TC), triglycerides (TG), and HDLcholesterol (HDL-C) was determined enzymatically by Hitachi 917 (Roche, Mannheim, Germany). LDL-cholesterol (LDL-C) was estimated among those with TG concentrations $<4.5 \mathrm{mmol} / \mathrm{L}$ as TC-HDL-C-TG/2.2. ${ }^{25}$ Those with TG $>4.5$ were measured directly by reagents from the same manufacturer. ${ }^{26}$ Between-run imprecision (CVs) for TC, TG, and measured LDL-C were 3.0\%, 4.0\%, and 2.0\%, respectively.

Normal fasting ranges for serum leptin are directly correlated with the degree of adiposity, with BMI range 18-25 serum leptin levels for men $(3.8 \pm 1.8 \mu \mathrm{g} / \mathrm{L})$, and for women $(7.4 \pm 3.7 \mu \mathrm{g} / \mathrm{L})$. Serum leptin levels rise approximately 2.5 times faster in women per unit of BMI as compared with men. There was a diurnal rhythm of serum leptin concentrations, the values being $20 \%$ to $40 \%$ higher in the middle of the night as compared with daytime. ${ }^{27,28}$ The peak shifts are in parallel with shifts in the timing of meals. ${ }^{29}$

\section{High-sensitivity C-reactive protein test}

Quantitative determination of human CRP in serum or plasma was by rate turbidimetry using IMMAGE ${ }^{\circledR} \mathrm{CRPH}$ reagent (Beckman Coutler, Fullerton, CA) which is based on the highly sensitive near-infrared particle immunoassay rate methodology. An anti-CRP antibody-coated particle binds to CRP in the patient sample, which results in the formation of insoluble aggregates that cause turbidity. The rate of aggregate formation is directly proportional to the concentration of CRP in the sample. The IMMAGE immunochemistry system will automatically calculate results. The analytic range of the CRPH test is designed to detect C-reactive protein concentrations using an initial undiluted (neat) serum sample. The Beckman Coulter analytical range is from an initial 0.02 to $6.0 \mathrm{mg} / \mathrm{dL}$, and extended 0.02 to $144 \mathrm{mg} / \mathrm{dL}$. The reference interval is $<0.744 \mathrm{mg} / \mathrm{dL}$. The reference interval used a population of 615 apparently healthy, nonsmoking, aged $\geq 18$ years, male and female adults from a southern California blood bank (as we did not establish our specific reference intervals yet $).{ }^{30}$

\section{Statistical analysis}

The data were analyzed by SPSS software (SPSS Inc, Chicago, IL). ${ }^{31}$ Data were expressed as mean and standard deviation (SD) unless otherwise stated. Student's $t$-test was used to ascertain the significant difference between mean values of two continuous variables and was confirmed by nonparametric Mann-Whitney $U$ test. Fisher's exact and Chi square tests were performed to test for difference in proportions of categorical variables between two and more groups. The Pearson's correlation coefficient and Spearman correlations were used to evaluate the strength association between two variables. $P<0.05$ was considered as the cutoff value for significance.

\section{Results}

Baseline clinical characteristics showed that $80.4 \%$ of patients were male and $19.6 \%$ were female: half were Qatari nationals; $67.9 \%$ were aged $>50$ years; $53.6 \%$ had well-controlled heart failure; $83.9 \%$ were in NYHA class I-II; $80.4 \%$ had stable angina pectoris; $17.9 \%$ had previous $\mathrm{MI} ; 19.6 \%$ had previous CABG; $8.9 \%$ had previous PCI; $28.6 \%$ had mitral valve replacement; $10.7 \%$ had aortic valve replacement; $35.7 \%$ had diabetes mellitus, $25 \%$ of which required insulin; $41.1 \%$ had hypertension; $37.5 \%$ had hypercholesterolemia; and $7.1 \%$ were smokers. Sixteen patients $(28.65 \%)$ have BMI $<25,48.2 \%$ were overweight, ${ }^{25-30}$ and $23.2 \%$ were obese. Systolic and diastolic blood pressures of the studied patients were (mean \pm SD) $123.91 \pm 8.67$ and $80.44 \pm 3.92$, respectively.

\section{ECG findings}

Normal sinus rhythm was found in $85.7 \%, 1.8 \%$ had old MI, $8.9 \%$ had atrial fibrillation, and $3.6 \%$ had left bundle branch block.

\section{Medication during fasting}

Medications taken by patients during Ramadan fasting were: aspirin, 60.7\%; warfarin, 26.8\%; angiotensin-converting enzyme inhibitors, $41.1 \%$; $\beta$-blockers, $55.4 \%$; nitrate, $32.1 \%$; calcium channel blockers, $19.6 \%$; statins, $51.8 \%$; nonsteroidal anti-inflammatory drugs, $12.5 \%$. Only $3.6 \%$ developed simple bacterial infections.

\section{Echocardiographic findings}

The mean $\pm \mathrm{SD}$ of $\mathrm{EF} \%$ of the studied patients was $54.75 \pm$ 14.05 and the mean \pm SD right ventricular systolic pressure (RVSP) were $36.21 \pm 11.29$.

\section{Angiographic findings}

Angiography found that $10.7 \%$ had single vessel disease, $1.8 \%$ had two-vessel disease while $19.6 \%$ had three-vessel disease (Table 1). 
Table I Baseline clinical characteristics, biochemical profile, therapy, and outcome $\mathrm{N}=56$

\begin{tabular}{|c|c|}
\hline Variables & n (\%) \\
\hline \multicolumn{2}{|l|}{ Gender } \\
\hline Male & $45(80.4)$ \\
\hline Female & II (19.6) \\
\hline \multicolumn{2}{|l|}{ Nationality } \\
\hline Qatari & $28(50.0)$ \\
\hline Non-Qatari & $28(50.0)$ \\
\hline \multicolumn{2}{|l|}{ Age group } \\
\hline$\leq 50$ & $18(32.1)$ \\
\hline$>50$ & $38(67.9)$ \\
\hline \multicolumn{2}{|l|}{ Congestive heart failure } \\
\hline Yes & $30(53.6)$ \\
\hline No & $26(46.4)$ \\
\hline \multicolumn{2}{|l|}{ Clinical finding } \\
\hline NYHA class I-II & 47 (83.9) \\
\hline Angina & $45(80.4)$ \\
\hline Previous MI & $10(17.9)$ \\
\hline Previous CABG & II (19.6) \\
\hline Previous $\mathrm{PCl}$ & $5(8.9)$ \\
\hline MVR & $16(28.6)$ \\
\hline AVR & $6(10.7)$ \\
\hline \multicolumn{2}{|l|}{ Risk factors } \\
\hline Diabetes mellitus & $20(35.7)$ \\
\hline Insulin required & $5(8.9)$ \\
\hline Hypertension & $23(4 I .1)$ \\
\hline Hypercholesterolemia & $21(37.5)$ \\
\hline Smoking & $4(7.1)$ \\
\hline Baseline heart rate (Mean \pm SD) & $84.79 \pm 10.77$ \\
\hline \multicolumn{2}{|l|}{ BMI } \\
\hline Acceptable $(<25)$ & $16(28.6)$ \\
\hline Overweight (25-30) & $27(48.2)$ \\
\hline Obesity $(>30)$ & $13(23.2)$ \\
\hline \multicolumn{2}{|l|}{ Blood pressure } \\
\hline Systolic (Mean \pm SD) & $|23.9| \pm 8.67$ \\
\hline Diastolic (Mean \pm SD) & $80.44 \pm 3.92$ \\
\hline \multicolumn{2}{|l|}{ ECG } \\
\hline NSR & $48(85.7)$ \\
\hline Old MI & $\mathrm{I}(\mathrm{I} .8)$ \\
\hline Atrial fibrillation & $5(8.9)$ \\
\hline LBBB & $2(3.6)$ \\
\hline \multicolumn{2}{|l|}{ Medication taken during fasting } \\
\hline Aspirin & $34(60.7)$ \\
\hline Warfarin & $15(26.8)$ \\
\hline ACE inhibitors & $23(4 I .1)$ \\
\hline$\beta$-blockers & $31(55.4)$ \\
\hline Nitrates & $18(32.1)$ \\
\hline Calcium channel blockers & II (19.6) \\
\hline Statins & $29(51.8)$ \\
\hline NSAID & $7(12.5)$ \\
\hline Infection & $2(3.6)$ \\
\hline \multicolumn{2}{|l|}{ Echocardiographic findings } \\
\hline $\mathrm{EF} \%($ Mean $\pm \mathrm{SD})$ & $54.75 \pm 14.05$ \\
\hline RVSP (Mean \pm SD) & $36.21 \pm 11.29$ \\
\hline \multicolumn{2}{|l|}{ Angiographic findings } \\
\hline SVD & $6(10.7)$ \\
\hline $2 V D$ & $\mathrm{I}(\mathrm{I} .8)$ \\
\hline $3 V D$ & II (19.6) \\
\hline
\end{tabular}

Abbreviations: $A C E$, angiotensin-converting enzyme; $A V R$, aortic valve replacement; BMI, body mass index; CABG, coronary artery bypass graft; EF, ejection fraction; MI, myocardial infarction; MVR, mitral valve replacement; NSAID, nonsteroidal antiinflammatory drug; NYHA, New York Heart Association; $\mathrm{PCl}$, percutaneous coronary intervention; RVSP, right ventricular systolic pressure; SD, standard deviation; SVD, single vessel disease; VD, vessel disease.

\section{Clinical course during fasting}

All patients fasted during Ramadan, $71.4 \%$ had no change in their symptoms during Ramadan, while $28.6 \%$ felt better during Ramadan. No patients deteriorated. $91.1 \%$ of the patients were compliant with medicine during Ramadan and 73.2\% after Ramadan, $89.3 \%$ were compliant with their diet during Ramadan. There was no significant change in body weight before, during, and after Ramadan with any cardiac or noncardiac morbidity or mortality (Table 2 ).

\section{Lipid profile during Ramadan}

No statistical significant changes were seen in TC $(5.35 \pm 0.99,5.58 \pm 0.99,5.50 \pm 0.9)$ and TG $(5.50 \pm 0.99$, $2.21 \pm 1.56,1.92 \pm 1.09 ; P>0.05)$ before, during, and after Ramadan, respectively. HDL-C decreased significantly during Ramadan than before fasting $(1.05 \pm 0.25 \mathrm{vs}$ $1.12 \pm 0.24 ; P=0.012$ ), respectively, but LDL-C significantly increased during fasting than before fasting $(3.31 \pm 0.97 \mathrm{vs}$ $3.59 \pm 0.92 ; P=0.022$ ), respectively (Table 3 ). No significant changes in serum hs-CRP were found before, during, and after fasting $(0.90 \pm 1.84,0.57 \pm 0.46,0.81 \pm 0.80$; $P>0.05$ ), respectively (Table 3 ). No significant changes in serum leptin were found before, during, and after fasting $(12.25 \pm 10.52,12.71 \pm 10.58,10.86 \pm 10.30, P>0.05)$, respectively (Table 3 ).

Spearman correlations showed significant correlation between hs-CRP and serum leptin before, during and after Ramadan $(P<0.05)$. No significant correlation was found between TC, TG, HDL-C, and LDL-C $(P>0.05)$ (Table 4).

Spearman correlations showed no significant correlation between TC, TG, HDL-C, and LDL-C $(P>0.05)$. There is significant correlation between TC and hs-CRP during Ramadan $(P=0.036)$ (Table 5).

Table 2 Follow up during the study period $(N=56)$

\begin{tabular}{|c|c|c|}
\hline Variables & During Ramadan & After Ramadan \\
\hline \multicolumn{3}{|l|}{ How does he/she feel? } \\
\hline Same as before & $40(7 \mid .4)$ & - \\
\hline Better than before & $16(28.6)$ & - \\
\hline Worse than before & - & - \\
\hline \multicolumn{3}{|c|}{ Patient compliance with medicine } \\
\hline Yes & 51 (9I.I) & $4 I(73.2)$ \\
\hline No & $5(8.9)$ & $15(26.8)$ \\
\hline \multicolumn{3}{|c|}{ Patient compliance with diet } \\
\hline Yes & $50(89.3)$ & $4 I(73.2)$ \\
\hline No & $6(10.7)$ & $15(26.8)$ \\
\hline \multicolumn{3}{|l|}{ Is patient fasting? } \\
\hline Yes & $56(100)$ & 51 (9I.I) \\
\hline No & $0(0.0)$ & $5(8.9)$ \\
\hline \multicolumn{3}{|l|}{ Body weight } \\
\hline Mean \pm SD & $78.91 \pm 14.89$ & $79.00 \pm 14.52$ \\
\hline
\end{tabular}

Abbreviation: $S D$, standard deviation. 
Table 3 Laboratory findings of patients before, during, and after Ramadan $(\mathrm{N}=56)$

\begin{tabular}{lccc}
\hline Variables & Before Ramadan & During Ramadan & After Ramadan \\
\hline Serum leptin & $12.25 \pm 10.52$ & $12.71 \pm 10.58$ & $10.86 \pm 10.30$ \\
Total serum cholesterol & $5.35 \pm 0.99$ & $5.58 \pm 0.99$ & $5.50 \pm 0.99$ \\
Triglyceride & $2.06 \pm 0.94$ & $2.21 \pm 1.56$ & $1.92 \pm 1.09$ \\
High-density lipoprotein-cholesterol & $1.12 \pm 0.24^{*}$ & $1.05 \pm 0.25$ & $1.08 \pm 0.25$ \\
Low-density lipoprotein-cholesterol & $3.31 \pm 0.97 * *$ & $3.59 \pm 0.92$ & $3.58 \pm 0.93$ \\
hs-C-reactive protein & $0.90 \pm 1.84$ & $0.57 \pm 0.46$ & $0.81 \pm 0.80$ \\
\hline
\end{tabular}

Notes: $* P=0.012$ for before Ramadan vs during Ramadan; $* * P=0.022$ for before Ramadan vs after Ramadan.

\section{Discussion}

Despite the fact that more than a billion Muslims worldwide practice fasting during Ramadan, the data on outcome of patients with cardiac disease who were fasting during Ramadan is lacking. Fasting in Ramadan may have negative effects on patients with cardiovascular disease. The fasting obligation that the daily calorie intake has to be taken in one or two meals instead of three to five is an effort. On the other hand, fasting may be protective; hunger has been associated with catecholamine inhibition (catecholamine surge has been implicated as a trigger for acute coronary syndrome) and reduced venous return causes a decrease in the sympathetic tone, which leads to a fall

Table 4 Spearman correlations between leptin, total cholesterol, LDL-C, HDL-C, triglyceride, and CRP

\begin{tabular}{|c|c|c|c|}
\hline \multirow[t]{3}{*}{ Variables } & Before Ramadan & During Ramadan & After Ramadan \\
\hline & $\mathbf{R}$ & $\mathbf{R}$ & $\mathbf{R}$ \\
\hline & $P$-value & $P$-value & $P$-value \\
\hline \multicolumn{4}{|c|}{ Serum leptin (before Ramadan) } \\
\hline \multirow[t]{2}{*}{ Total serum cholesterol } & 0.049 & 0.007 & -0.008 \\
\hline & 0.791 & 0.971 & 0.966 \\
\hline \multirow[t]{2}{*}{ Triglyceride } & -0.015 & -0.042 & -0.148 \\
\hline & 0.937 & 0.824 & 0.419 \\
\hline \multirow[t]{2}{*}{ HDL-C } & 0.095 & 0.128 & 0.079 \\
\hline & 0.606 & 0.499 & 0.666 \\
\hline \multirow[t]{2}{*}{ LDL-C } & 0.035 & 0.040 & -0.004 \\
\hline & 0.848 & 0.834 & 0.984 \\
\hline \multirow[t]{2}{*}{ hs-C-reactive protein } & $0.345^{*}$ & $0.359 *$ & $0.398 *$ \\
\hline & 0.042 & 0.034 & 0.018 \\
\hline \multicolumn{4}{|c|}{ Serum leptin (during Ramadan) } \\
\hline \multirow[t]{2}{*}{ Total serum cholesterol } & 0.017 & 0.013 & 0.002 \\
\hline & 0.925 & 0.944 & 0.991 \\
\hline \multirow[t]{2}{*}{ Triglyceride } & -0.037 & 0.008 & -0.183 \\
\hline & 0.838 & 0.966 & 0.307 \\
\hline \multirow[t]{2}{*}{ HDL-C } & 0.062 & 0.031 & -0.008 \\
\hline & 0.733 & 0.868 & 0.963 \\
\hline \multirow[t]{2}{*}{ LDL-C } & 0.015 & 0.061 & 0.035 \\
\hline & 0.935 & 0.745 & 0.847 \\
\hline \multirow[t]{2}{*}{ hs-C-reactive protein } & 0.234 & $0.354^{*}$ & $0.387^{*}$ \\
\hline & 0.170 & 0.034 & 0.020 \\
\hline \multicolumn{4}{|c|}{ Serum leptin (after Ramadan) } \\
\hline \multirow[t]{2}{*}{ Total serum cholesterol } & -0.081 & 0.035 & -0.052 \\
\hline & 0.655 & 0.852 & 0.772 \\
\hline \multirow[t]{2}{*}{ Triglyceride } & -0.115 & -0.147 & -0.299 \\
\hline & 0.526 & 0.429 & 0.091 \\
\hline \multirow[t]{2}{*}{ HDL-C } & 0.082 & 0.132 & 0.091 \\
\hline & 0.650 & 0.479 & 0.613 \\
\hline \multirow[t]{2}{*}{ LDL-C } & -0.053 & 0.010 & -0.014 \\
\hline & 0.770 & 0.957 & 0.939 \\
\hline \multirow{2}{*}{ hs-C-reactive protein } & 0.254 & $0.338^{*}$ & 0.243 \\
\hline & 0.135 & 0.044 & 0.153 \\
\hline
\end{tabular}

Note: $*$ P-value $<0.05$.

Abbreviations: HDL-C, high-density lipoprotein cholesterol; LDL-C, low-density lipoprotein cholesterol. 
Table 5 Spearman correlations between C-reactive protein, cholesterol, LDL, HDL, and triglycerides

\begin{tabular}{|c|c|c|c|}
\hline \multirow[t]{3}{*}{ Variables } & Before Ramadan & During Ramadan & After Ramadan \\
\hline & $\mathbf{R}$ & $\mathbf{R}$ & $\mathbf{R}$ \\
\hline & $P$-value & $P$-value & $P$-value \\
\hline \multicolumn{4}{|c|}{ hs-C-reactive protein (before Ramadan) } \\
\hline \multirow[t]{2}{*}{ Total serum cholesterol } & -0.284 & 0.120 & 0.179 \\
\hline & 0.109 & 0.520 & 0.319 \\
\hline \multirow[t]{2}{*}{ Triglyceride } & 0.18 & 0.192 & 0.035 \\
\hline & 0.921 & 0.302 & 0.846 \\
\hline \multirow[t]{2}{*}{ HDL-C } & -0.124 & 0.003 & 0.059 \\
\hline & 0.493 & 0.987 & 0.745 \\
\hline \multirow[t]{2}{*}{ LDL-C } & -0.189 & -0.059 & 0.110 \\
\hline & 0.292 & 0.751 & 0.541 \\
\hline \multicolumn{4}{|c|}{ hs-C-reactive protein (during Ramadan) } \\
\hline \multirow[t]{2}{*}{ Total serum cholesterol } & -0.366 & $0.036 *$ & -0.022 \\
\hline & 0.036 & 0.845 & 0.902 \\
\hline \multirow[t]{2}{*}{ Triglyceride } & -0.079 & 0.128 & -0.083 \\
\hline & 0.662 & 0.494 & 0.646 \\
\hline \multirow{2}{*}{ HDL-C } & -0.083 & 0.084 & 0.105 \\
\hline & 0.647 & 0.652 & 0.560 \\
\hline \multirow[t]{2}{*}{ LDL-C } & -0.279 & 0.131 & -0.039 \\
\hline & 0.115 & 0.484 & 0.828 \\
\hline \multicolumn{4}{|c|}{ C-reactive protein (after Ramadan) } \\
\hline \multirow[t]{2}{*}{ Total serum cholesterol } & -0.037 & 0.039 & 0.007 \\
\hline & 0.839 & 0.837 & 0.971 \\
\hline \multirow[t]{2}{*}{ Triglyceride } & 0.066 & 0.232 & 0.061 \\
\hline & 0.714 & 0.209 & 0.736 \\
\hline \multirow[t]{2}{*}{ HDL-C } & -0.219 & -0.234 & -0.239 \\
\hline & 0.221 & 0.204 & 0.181 \\
\hline \multirow[t]{2}{*}{ LDL-C } & 0.051 & 0.000 & 0.170 \\
\hline & 0.780 & 0.998 & 0.345 \\
\hline
\end{tabular}

Note: $*$-value $<0.05$.

Abbreviations: HDL-C, high-density lipoprotein cholesterol; LDL-C, low-density lipoprotein cholesterol.

in blood pressure, heart rate and cardiac output. ${ }^{2}$ Moreover, Perk and colleagues ${ }^{32}$ reported a reduced heart rate during Ramadan. This could be due to the inhibition of catecholamine production during hunger. ${ }^{32}$ To the best of our knowledge, this is the first study to comprehensively analyze clinical findings in correlation with the serum leptin, which was found to have a role in acute coronary syndrome, and in correlation with hs-CRP, the well-known inflammatory marker.

In the current study, all patients of different functional classes were cardiac patients and they finished fasting during Ramadan without any reported cardiac or noncardiac event in spite of their different nationalities and thus different lifestyle and dietary habits. Nearly $90 \%$ of them were compliant with medication (most of the cardiac medications are single-dose medications) and diet.

Studies on the effect of Ramadan fasting on blood lipids have produced variable results. Serum cholesterol may decrease in the first days of fasting and rise to prefasting values. Some studies have reported raised concentrations of cholesterol, which may be related to weight loss during Ramadan fasting. However, others have found no change, or only decreased levels of cholesterol during fasting. ${ }^{5-9}$ The evidence that a marked increase in plasma HDL-C occurs after Ramadan fasting is promising. ${ }^{33-36}$ This is in contrast to our current study, which found a significant decrease in HDL-C and an increase in LDL-C with no reflection on overall clinical status probably because of its short duration. Changes in blood lipids seem to be variable and depend probably on the quality and quantity of food consumption and the degree of weight changes in the patient.

Leptin was found to have multiple roles in the cardiovascular system as a vasoactive substance, in coronary artery vasoreactivity, in regulation of myocardial blood flow, ${ }^{17}$ and it may have a prothrombotic effect. ${ }^{18}$ Leptin levels may increase with acute MI. ${ }^{19}$ In the current study, in spite of the impact of Ramadan fasting on the diurnal rhythm of eating and sleeping, mean serum leptin shows no change during fasting when compared with that before and after fasting. This can be explained by the compliance of cardiac patients with diet and caloric intake and with no change in body weight $(89.3 \%)$. 
In contradiction to other studies that show that serum leptin significantly increases by approximately $41 \%$, the explanation for this difference is that the studies were conducted on healthy female volunteers during Ramadan who show an increased energy intake as measured by kilocalories/ day, but with no change in body weight or BMI. ${ }^{37}$ The clinical follow-up of our patients with no clinical event reported was compatible with our previous Gulf multicenter study. ${ }^{23}$

The role of CRP in cardiac disease has been raised by many studies as an acute phase-reactant protein. Serum CRP is significantly associated with other cardiovascular risk factors. The highest values of serum CRP have been observed in patients with the greatest number of cardiovascular risk factors, which suggests that it may be a useful clinical marker for future cardiovascular events. ${ }^{38-41}$ Among patients with known stable coronary disease, a correlation between serum CRP and acute coronary events has been demonstrated in some studies. ${ }^{10-12}$ In the current study, hs-CRP serum levels continue to show the same levels before, during, and after Ramadan, which is compatible with clinical follow-up of stable cardiac patients during fasting Ramadan.

Previous studies have shown that CRP levels increase continuously across the spectrum of fasting glucose in nondiabetics ${ }^{13,14}$ and that CRP is independently associated with fasting hyperinsulinemia in nondiabetic women. ${ }^{15}$ Other studies show that CRP levels are more strongly associated with postchallenge glycemia than with fasting glucose levels in nondiabetic subjects. This association is partially independent of body fat and insulin resistance. ${ }^{16} \mathrm{In}$ the current study, although $35.7 \%$ of patients were diabetic and $8.9 \%$ required insulin, we did not observe any fluctuation in CRP during the follow-up period. Moreover studies have shown that in young, apparently healthy men, serum leptin, but not BMI, was independently associated with serum CRP, which suggests that the amount of body fat may be the most significant predictor of CRP. ${ }^{20}$ The current study also showed a significant correlation in hs-CRP and serum leptin before, during, and after Ramadan $(P<0.05)$. The importance of such a correlation needs to be explored in further studies.

\section{Conclusion}

Ramadan fasting, a prolonged, strict, and stressful event, in stable cardiac patients has no negative impact on clinical status, serum leptin or hs-CRP, but results in decreased HDL-C and an increase in LDL-C. Significant correlations between hs-CRP and TC were found, but not in any other component lipid profile. A significant correlation was observed between hs-CRP and serum leptin. No significant correlation was found between serum leptin, TC, HDL-C, TG, or LDL-C.

\section{Study limitations}

This study included a small number of stable cardiac patients with many risk factors for coronary artery disease. Unstable cardiac patients were excluded for ethical reasons. A larger sample is needed in future studies to confirm the current result. The results of this study complement our previous studies. It included patients from different cultures and education levels. The answer to the cardiac patient's question about fasting during Ramadan has been found. However, the decision to fast should be individualized to every patient according to their clinical status.

\section{Disclosure}

The authors report no conflicts of interest in this work.

\section{References}

1. Sakr AH. Fasting in Islam. J Am Diet Assoc. 1975;67:17-21.

2. Azizi F. Medical aspects of Islamic fasting. Med J Islamic Rep Iran. 1996;10:241-246.

3. Al Suwaidi J, Bener A, Hajar HA, Numan MT. Does hospitalization for congestive heart failure occur more frequently in Ramadan: a population based study. Int J Cardiol. 2004;96(2):217-221.

4. Proceedings of the Second International Congress on Health and Ramadan; December 1-3, 1997; Istanbul, Turkey.

5. El-Hazmi MAF, A1-Faleh FZ, Al-Mofleh IB. Effect of Ramadan fasting on the values of hematological and biochemical parameters. Saudi Med J. 1987;8:171-176.

6. Gumaa KA, Mustafa KY, Mahmoud NA, et al. The effect of fasting in Ramadan. 1. Serum uric acid and lipid concentrations. Br J Nutr. 1978; 40(3):573-581.

7. Fedail SS, Murphy D, Salih SY, et al. Changes in certain blood constituents during Ramadan. Am J Clin Nutr. 1982;36:350-353.

8. Shoukry MI. Effect of fasting in Ramadan on plasma lipoproteins and apoproteins. Saudi Med J. 1986;7:561-565.

9. Hallak MH, Nomani MZA. Body weight loss and changes in blood lipid level in normal men on hypocaloric diets during Ramadan fasting. Am J Clin Nutr. 1988;8:1197-1210.

10. Zebrack JS, Muhlestein JB, Horne BD, et al. C-reactive protein and angiographic coronary artery disease: independent and additive predictors of risk in subjects with angina. J Am Coll Cardiol. 2002;39: 632-637.

11. Bogaty P, Poirier P, Simard S, et al. Biological profiles in subjects with recurrent acute coronary events compared with subjects with longstanding stable angina. Circulation. 2001;103:3062-3068.

12. Thompson SG, Kienast J, Pyke SDM, et al. Hemostatic factors and the risk of myocardial infarction or sudden death in patients with angina pectoris. European Concerted Action on Thrombosis and Disabilities Angina Pectoris Study Group. N Engl J Med. 1995;332:635-641.

13. Nakanishi N, Shiraishi T, Wada M. Association between fasting glucose and C-reactive protein in a Japanese population: the Minoh study. Diabetes Res Clin Pract. 2005;69(1):88-98.

14. Aronson D, Bartha P, Zinder O, et al. Association between fasting glucose and C-reactive protein in middle-aged subjects. Diabet Med. 2004;21(1):39-44.

15. Pradhan AD, Cook NR, Buring JE, et al. C-reactive protein is independently associated with fasting insulin in nondiabetic women. Arterioscler Thromb Vasc Biol. 2003;23(4):650-655. 
16. Festa A, D'Agostino R Jr, Tracy RP, Hafner SM. C-reactive protein is more strongly related to post-glucose load glucose than to fasting glucose in non-diabetic subjects; the Insulin Resistance Atherosclerosis Study. Diabet Med. 2002;19(11):939-943.

17. Sundell J, Huuppon R, Raitakari OT, Nuutila P, Knuuti J. High serum leptin is associated with attenuated coronary vasoreactivity. Obes Res. 2003;11(6):776-782.

18. Bodary PF, Westrick RJ, Wickenheiser KJ, et al. Effect of leptin on arterial thrombosis following vascular injury in mice. JAMA. 2002;287(13):1706-1709.

19. Piestrzeniewicz K, Luczak K, Komorowski J, Maciejewski M, Goch JH. The relationship between leptin and obesity and cardiovascular risk factors in men with acute myocardial infarction. Cardiol J. 2007;14(3):252-259.

20. Kazumi T, Kawaguchi A, Hirano T, et al. C-reactive protein in young, apparently healthy men: associations with serum leptin, QTc interval, and high-density lipoprotein-cholesterol. Metabolism. 2003;52(9):1113-1116.

21. Al Suwaidi J, Bener A, Salam AM, et al. Does fasting alter the circadian pattern of acute cardiac events? J Postgrad Med. 2006;52:30-33.

22. Al Suwaidi J, Bener A, Hajar HA, et al. A population-based study of Ramadan fasting and acute coronary syndromes (1991-2001). Heart. 2004;90:695-696.

23. Al Suwaidi J, Zubaid M, Al Mahmeed WA, et al. Impact of fasting in Ramadan in patient with cardiac disease; a multi-center prospective study. Saudi Med J. 2005;26(10):1579-1583.

24. Ma Z, Gingerich RL, Santiago JV, Klein S, Smith CH, Landt M. Radioimmunoassay of leptin in human plasma. Clin Chem. 1996;42: 942-946.

25. Fridewald WF, Levy RI, Frederickson DS. Estimation of LDL-cholesterol concentration without use of the preparative ultra-centrifuge. Clin Chem. 1972;18:499-502.

26. Nauck M, Warnick GR, Rifai N. Methods for measurement of LDLcholesterol: a critical assessment of direct measurement by homogeneous assays versus calculation. Clin Chem. 2002;48:236-254.

27. Boden G, Chen X, Kolaczynski JW, et al. Effects of prolonged hyperinsulinemia on serum leptin in normal human subjects. J Clin Invest. 1997;100:1107-1113.

28. Licinio J, Negrao AB, Mantzoros C, et al. Synchronicity of frequently sampled, 24-h concentrations of circulating leptin, luteinizing hormone, and estradiol in healthy women. Proc Natl Acad Sci U S A. 1998;95:2541-2546.
29. Schoeller DA, Cella LK, Sinha MK, et al. Entrainment of the diurnal rhythm of plasma leptin to meal timing. J Clin Invest. 1997;100: 1882-1887.

30. Ridker PM. High-sensitivity C-reactive protein and cardiovascular risk: rationale for screening and primary prevention. Am J Cardiol. 2003;92(4B): $17 \mathrm{~K}-22 \mathrm{~K}$

31. Norusis MJ. SPSS/PC+ for Windows. Base System and Advanced Statistical User's Guide. Windows Version \#12. Chicago, IL: SPSS Inc; 1998.

32. Perk G, Ghanem J, Aamar S, Ben-Ishay D, Bursztyn M. The effect of the fast of Ramadan on ambulatory blood pressure in treated hypertensives. J Hum Hypertens. 2001;15:723-725.

33. Maislos M, Khamaysi N, Assali A, Abou-Rabiah Y, Zvili I, Shany S. Marked increase in plasma high-density lipoprotein cholesterol after prolonged fasting during Ramadan. Am J Clin Nutr. 1993;57:60-62.

34. Maislos M, Abou-Rabiah Y, Zuili I, Iordash S, Shany S. Gorging and plasma HDL-cholesterol: the Ramadan model. Eur J Clin Nutr. 1998;52:127-130.

35. Adlouni A, Ghalim N, Benslimane A, Lecery JM, Saile R. Fasting during Ramadan induces a marked increase in HDL and decrease in LDL-cholesterol. Ann Nutr Metab. 1997;1:22-29.

36. Temizhan A, Tandogan I, Donderici O, et al. The effects of Ramadan fasting on blood lipid levels. Am J Med. 2000;109:341-342.

37. Kassab S, Abdul Ghafar T, Nagalla S, et al. Interaction between leptin, neuropeptide-Y and insulin with chronic diurnal fasting during Ramadan. Ann Saudi Med. 2004;24(5):345-349.

38. Ridker PM. Clinical application of C-reactive protein for cardiovascular disease detection and prevention. Circulation. 2003;107:363-369.

39. Ridker PM, Buring JE, Cook NR, Rifai N. C-reactive protein, the metabolic syndrome, and risk of incident cardiovascular events: an 8-year follow-up of 14719 initially healthy American women. Circulation. 2003;107:391-397.

40. Rutter MK, Meigs JB, Sullivan LM, et al. C-reactive protein, the metabolic syndrome, and prediction of cardiovascular events in the Framingham Offspring Study. Circulation. 2004;110:380-385.

41. Rohde LE, Hennekens CH, Ridker PM. Survey of C-reactive protein and cardiovascular risk factors in apparently healthy men. Am J Cardiol. 1999;84:1018-1022.
Vascular Health and Risk Management

\section{Publish your work in this journal}

Vascular Health and Risk Management is an international, peerreviewed journal of therapeutics and risk management, focusing on concise rapid reporting of clinical studies on the processes involved in the maintenance of vascular health; the monitoring, prevention and treatment of vascular disease and its sequelae; and the involvement of

\section{Dovepress}

metabolic disorders, particularly diabetes. This journal is indexed on PubMed Central and MedLine. The manuscript management system is completely online and includes a very quick and fair peer-review system, which is all easy to use. Visit http://www.dovepress.com/ testimonials.php to read real quotes from published authors. 